\title{
1925年パリ現代装飾美術・工芸美術国際博覧会の会場計画に関する考察 A STUDY ON THE SITE PLANNINGS FOR THE INTERNATIONAL EXPOSITION OF MODERN DECORATIVE AND INDUSTRIAL ARTS IN PARIS 1925
}

\author{
三田村 哲哉*，小林 克 弘** \\ Tetsuya MITAMURA and Katsuhiro KOBAYASHI
}

\begin{abstract}
Through a study on the periodical transitions of the site plannings for the International Exposition of Modern Decorative and Industrial Arts in Paris 1925, the followings were made clear : 1) Louis bonnier made the principles and the solutions for problems of the site and the significances of this Exposition, and they gave a sense of unity to the site plan. 2) He gave orders to sites, scales, and forms of gallaries and independent pavilions for the site plan.
\end{abstract}

\begin{abstract}
Keywords : "International Exposition of Modern Decorative and Industrial Arts in Paris 1925", Esplanade des Invalides, Grand Palais, Louis Bonnier, Charles Plumet, Site Planning 1925 年パリ現代装飾美術・工芸美術国際博覧会、エスプラナード・デ・ザンヴァリッド、 グラン・パレ、ルイ・ボニエ、シャルル・プリュメ、会場計画
\end{abstract}

\section{1. 序}

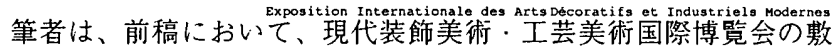
地選考から決定に至る一連の検討過程に関する考察を行った。その

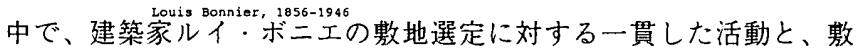
地の抱える条件及び問題点を明らかにした1。本稿は、その結果を受 けて、本博覧会の会場の計画過程を明らかにするものである。本考 察では、この計画過程をより明確に描き出すため、敷地の抱える条 件及び問題点に対する対応だけではなく、本博覧会の開催意義の形 成において生じた条件に対する対応に関する分析も行った。加えて、 主要会場の1つであるエスプラナード・デ゙・ザンヴァリッドについ ては、独立館を中心により詳細な分析を行っている。

こうした本博覧会の会場計画に関する考察は、敷地選定に関する 考察と同様に極めてそしい2)。また、本考察は、会場の建築意匠学的 視座からの分析だけではなく、その背景にある会場計画に対する条 件等と、それらに対する対応に明確な考察の視点を向けている点に おいても、他と大きく異なるものである。さらに、各展示館が、こ の会場計画案を基に設計されたものであるため、本稿は、展示館の 建築造形に関する考察に対しても意味あるものとなろう。

考察の対象とした会場計画案は、主に配置図、鳥瞰図及び、その案 に関する報告書等からなる。また、これらの会場計画案は、当時を代
表する建築誌及び主要誌において随時発表された 協会において発表された 1 案及び、本博覧会に関する公式記録に掲載 された 1 案の計 6 案である ${ }^{3)}$ 。さらに、初めの 3 案に関しでは、それ ぞれの案に対するルイ・ボニエの報告書と、展示会場の面積と展示館 の平面外形または敷地形状に関する報告書についても考察を行った4。 加えて、エスプラナード・デ・ザンヴァリッドに関する分析は、配置 図の実施図面から各部の寸法を確認して、その精度を高めたものであ る5)。尚、この敷地に関しては、当時の測量図により、計画前の敷地 細部の形状、高低差等についても確認を行っている6)。

\section{2. 会場計画の条件一開催意義に関連した条件}

1921 年 11 月 7 日に、本博覧会の敷地は、植民地博覧会と協定を結 ふことによって、エスプラナード・デ・ザンヴァリッドとグラン゙・・パレ を中心とした地域に決定した。しかし、この敷地には、本博覧会の会 場計画案を描き出す際に、考慮すべき敷地に関連した条件と問題点が あった7)。一方、1911 年から本博覧会の開催意義に関する検討が継続 的に行われた。これに伴い、会場計画に直接影響を与える条件が生じ ていた。これらを整理すると次の 3 点にまとめることができる。

第1点目は、「フランスと諸外国との対置関係」である。これは、 フランスの装飾美術と諸外国の装飾美術を比較しょうとする認識が
* 東京都立大学大学院工学研究科建築学尃攻 博士課程・修士 (工学)

** 東京都立大学大学院工学研究科建築学専攻 教授・工博
Graduate Student, Dept. of Architecture, Faculty of Engineering, Graduate School of Tokyo Metropolitan Univ., M. Eng.

Prof., Dept. of Architecture, Faculty of Engineering, Graduate School of Tokyo Metropolitan Univ., Dr. Eng. 
高まっていたことを表している8〉。この認識が生じた理由は、フラン スが諸外国から装飾美術の分野における立ち後れを取っていたこと にさかのほる。しかし、フランスは、本博覧会において、その遅れ を克服し躍進していることを、諸外国の装飾美術と対置し比較する ことによって明らかにすることを目論み始めていた9)。

第 2 点目は、「展示物の「分類」」である。これは、博覧会でさま ざまな展示物を整理し、有効に展示するために用途や素材によって 仕分けを行う指標のことである ${ }^{10}$ 。本博覧会は、展示品が装飾美術 に限定されていることと、1900年パリ方国博覧会では、建築装飾に 関する「組」が2 Lか規定されなかったため、本博覧会の「展示物 の『分類』」を大きく発展させた ${ }^{111}$ 。具体的には、装飾美術に対して は「群」及び「組」による分類法へ発展し、最終的には5「群」、37 「組」に及ふ分類法が確立された ${ }^{12)}$ 。本博筧会においても同様に、こ の指標が会場を計画する際の大きな要因として影響を与えている。

第 3 点目は、「展示館の種類」である。本博筧会の展示館は、独立 館、ギャラリー、グラン・パレの 3 種から構成され、各展示館の種類 に基づいて分類される ${ }^{13)}$ 。一方、本博覧会の要求によって、諸外国及 び諸地域の特徴を表した建築を発表するために独立館を用意すること と、多くの展示物を陳列する展示空間を確保することが必要であっ た。そのため、前者には、独立館を建設する敷地を、後者には、各展 示室を設置できるグラン・パレを用意することが求められた。 さら に、ギャラリーは、より多くの展示空間の必要性と「植民地博覧会よ り委譲された際に課せられた条件」から考案されたものである ${ }^{14) 。 ~}$

\subsection{2 年 3 月案一独立館 30 棟案}

ルイ・ボニエは、1921年12月16日に会場計画案の基本方針をま とめている ${ }^{15)}$ 。さらに 2 ケ月後の 1922 年 2 月には、本博覧会の敷地 及び展示会場のおおよその各面積の配分を行った ${ }^{16) 。 こ の 中 て ゙ 、 ル ~}$ イ・ボニエは、「展示館の種類」に関連して、展示会場としてグラン. パレが利用できることと、「植民地博覧会より委譲された際に課せら れた条件」によりギャラリーを建設することを考慮して、展示館の 種類を独立館、ギャラリー、グラン・パレ及び、それ以外を屋外展 示とレストランなどのサービス部門の 4 点に分類している。

その上で、ルイ・ボニエは、「フランスと諸外国との对置関係」を 利用して、一つの方針を明らかにした。それは、全ての孉地の分配 に際し、ては、フランス部門の展示面積と、外国部門の展示面積を平等 に扱うことであり、これは面積計画においても明確に現れている17)。

さらに、ルイ・ボニエは、独立館、ギャラリー、グラン・パレの 3つの展示会場にそれぞれの個性を明確に与えるため、「展示物の 『分類」」を利用して異なる特徴を与えた。具体的には、それぞれの 展示品の展示場所を区別することによって、これらろつの展示会場 の特徴を明確に示そうとするものである ${ }^{18)}$

以上の上うに、本博覧会の基本方針は、開催意義に関する検討に

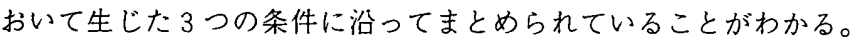
そして、この方針に沿って、独立館とギャラリーに関しても、より 具体的な方針が明らかにされた。まず、独立館が、「植民地博覧会よ り委譲された際に課せられた条件」によって、エスプラナード・デ.

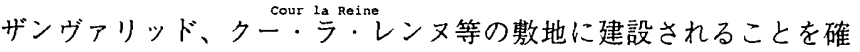
認した上で、次の 3 点の基本方針が示されている。第 1 点目は、独 立館には、 $350 \mathrm{~m}^{2}$ から $400 \mathrm{~m}^{2}$ の敷地面積を与え、約 30 棟を計画す
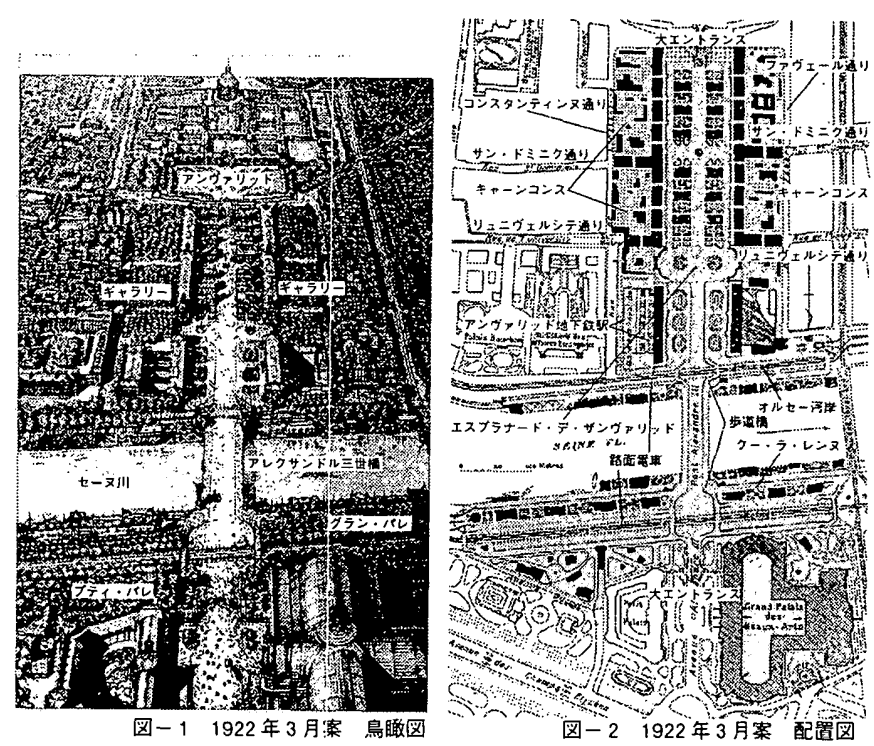

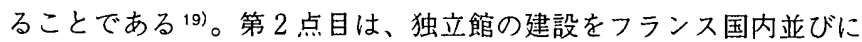
諸外国にも依頼するとともに、建築家だけではなく装飾美術のさま ざまな分野の専門家や職人のグループが、これに参加することを要求 している点である ${ }^{20)}$ 。第 3 点目は、この独立館は、他の展示館とは 異なる特徴を与えるために、「展示物の「分類」」に沿って、他の展 示館とは異なる外観と内部空間が求められている点である ${ }^{21) 。 ~}$

これに対してギャラリーには、2点の基本方針を挙げている。第】 点目は、「植民地博覧会より委譲された際に課せられた条件」によっ て、エスプラナード・デ・ザンヴァリッドに建設されることが決まっ

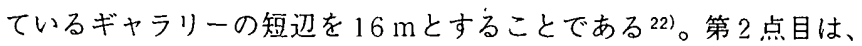
ギャラリーの背景にあるアンヴァリッドを視覚的に引き立たせるた めに、4 mの柱廊を設けることである。

ルイ・ボニエは、こうした基本方針を明確にした上で、1922 年 3 月 案を発表した（図-1、2) c この案の会場構成に関する特徵を整理する と次の5点にまとめることができる。第1点目は、エスプラナード． デ・ザンヴァリッドのアンヴァリッド側及び、グラン．パレと プティ・・゙レに挟まれたアレグサンドル 3 世通りの 2 カ所に大エント ランスが設けられている点である23)。第2 点目は、独立館が、十分な 間隔をとって庭園と交互に組み合わせて配置されている点である ${ }^{24)} 。$ 第3点目は、エスプラナード・デ・ザンヴァリッドのギャラリーが、両 側のキャーンゴンスに沿うように軸線対称な位置にそれぞれ計画され ている点である。第4点目は、「敷地の地理的及び周辺環境に伴う条件」 への対応として、オルセー河岸及びクー・ラ・レンヌの路面電車の軌 道部分を、歩道橋を設けることによって会場内の交通問題を解決しよ うとしている点である ${ }^{25)}$ 。第5点目は、エスプラナード・デ・ザンヴァ

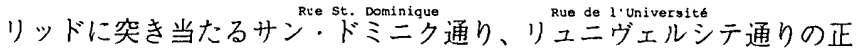
面には、それぞれ4 棟のギャラリーが設けられている点である。

このように、1.922 年3月案では、「フランスと諸外国との対置関 係」以外の敷地に関連した条件及び問題点と、開催意義に関連した 条件に対する対応を明らかにしていることがわかる。それらを考虑 した上で、会場をアンヴァリッドの軸性とセーヌ河岸の地形を活か したものとすることを、概念図に近い図面によって表している。

\section{1922 年 7 月案一独立館 60 棟案}

この会場計画案は、前案を基本として発展されたものである。具体的 
に、本案は、前案に描かれた「植民地博覧会より委譲された際に課 せられた条件」、「敷地の地理的及び周辺環境に伴う条件」、「展示物 の「分類】」、「展示館の種類」に対する対応を中心に基本方針を踏襲 したものである。ルイ・ボニエは、本案では、このような条件に対 する対応の検討を続けるのではなく、本案の精度を向上させることに よって前案を発展させている26)。こうした見方ができる理由は、本 案が、すべての展示館の数、平面外形または敷地外形及び、その面 積算定を基に描かれているからである27)。その面積精度の向上に見 られる特徴は、次の 3 点にまとめることができる。

第1点目は、独立館に関してである。会場の各地域に応じた独立 館が用意されているが、その地域ごとに独立館の短边が同じ長さの 平面形によって、平面外形または敷地外形が与えられている点であ る。例えば、エスプラナード・デ・ザンヴァリッドに計画される独 立館の平面の短辺には $11 \mathrm{~m}$ が与えられ、クー・ラ・レンヌにおいて は、 $8 \mathrm{~m}$ と $12 \mathrm{~m}$ が短辺の矩形または直径の円を平面外形または敷地 外形とする独立館が計画された ${ }^{28)}$ 。このように、独立館に対して平 面の大きさとその形状によって、会場計画に一秩序を与えている。

第 2 点目は、ギャラリーが前回の基本方針をさらに発展させて具 体化している点である。つまり、ギャラリーに対してグラン・ギャラ リーとプティ・ギャラリーという大小関係が与えられただけではなく、 すべてのギャラリーにそれぞれの平面外形及びその寸法が与えられ た29〉。さらに、前案の基本方針で示された展示会場の特徴を明確化 するという対応に沿って、グラン・パレとは異なる特徵ある展示を 行うために、すべてのギャラリー内に 1 辺が $6 \mathrm{~m}$ の正方形の展等場所 を合計 175 䉪所設けるという計画を綿密に行っている30)。

第 3 点目は、独立館と同様に、これに付設される庭園にも平面外 形または敷地外形と、その面積算定が正確に行われている点である。 これによって、その計画の精度を高めるとともに、独立館と庭園を 一体として捉えた会場を正確に描こうとする意図が明確に読み取れ る。このように、庭園が会場計画の中で重視されている理由は、本 博覧会において庭園が、独立館と同様に装飾美術の視点からも重要 なテーマとして扱われていたからである。さらに、こうした庭園は、 適度な間隔を空けてそれぞれの独立館を配置することを促し、それ らを魅力的に表現する効果を狙ったものでもある ${ }^{31) 。 ~}$

具体的に、本案と前案の相違点を明らかにし、本案の特徴を整理す ると、以下の5 点にまとめることができる(図-3)。第1点目は、アン ヴァツッド側に設けられていた大エシトランスを撤去し、図書館 と会議場が、軸線対称に描かれている点である ${ }^{32)}$ 。第 2 点目は、キャー ンコンスから多くの展示館が撤去され、ギャラリーによって囲まれた 中央部分に独立館を計画し、この部分をエスプラナード・デ・ザンヴァ リッドの中心会場とする意図が明確に表れている点である。第 3 点目 は、第 2 点目に伴って、ギャラリーが、それぞれ 2 力所のみエスプラ ナード・デ・ザンヴァリッドの中央部分からキャーンコンスへ抜ける 部分を残し、一体感のあるギャラリーへと変更された点である。加え て、図書館と会議場まで連続した回廊も設けた。第 4 点目は、路面電 車の軌道部分をセーヌ河岸側に迂回させ、さらに地下埋設化すること によって、オルセー河岸及びクー・ラ・レンヌを会場として全面的に 利用できるように改善した点である。これにより、前案において「敷 地の地理的及び周辺瑾境に伴う条件」の解決のために計画された歩道 橋も撤去された ${ }^{33)}$ 。第 5 点目は、独立館の数が 60 棟に増加され、その
一方で、それぞれの独立館の平面 の大きさは、約 $100 \mathrm{~m}^{2}$ から $250 \mathrm{~m}^{2}$ 程度に縮小されている点である。

本案は、前案で残った条件に対 する対応を、会場計画案の中に具 体的に描き出すのではなく、独立 館の面積とその数等、計画自体の 精度を向上させることによって、 アンヴァリッドの軸性とセーヌ河 岸の地形を活かした会場を描き出 すという前案の方針に沿った会場 計画をより具体化することを試み ている。

5. 1922 年 11 月案一独立館 78 棟案

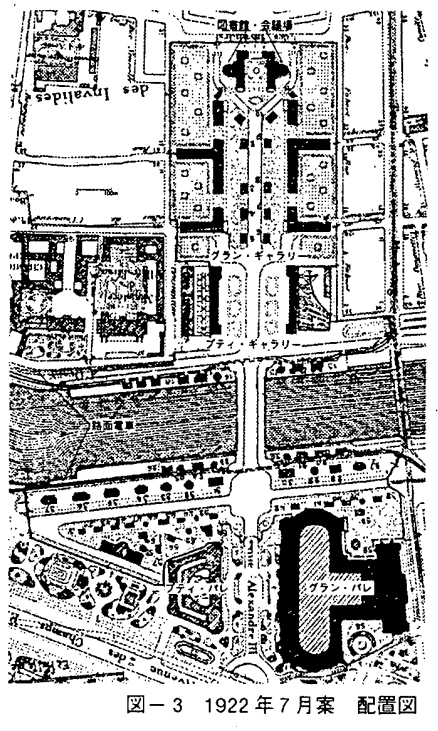

本案は、この博覧会開催を招待国に通知するための報告書に掲載

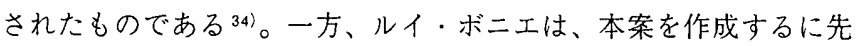

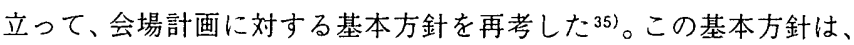
会場内に建設する建築の会場全体に対する配分と均整という2つの 視点からまとめ直したものである。

第1 点目は、本博覧会全体の光景を重視している点である。具体的 には、ルイ・ボニエは、アンヴァリッドの眺望を尊重するため、会場 の樹木、庭園、水面等の余空間を十分に取ることを重視している ${ }^{36) 。}$ これを基に、会場計画に関するより具体的な内容が決められた。ま ず、独立館に関しては、ギャラリーの両端に設けられた塔を除き、平

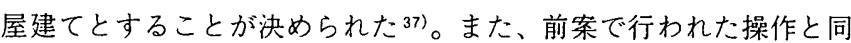
様に、独立館の平面形とその大きさを変更するとともに、その数を 60 棟から 78 棟に增加させている。特にエスプラナード・デ .ザン ヴァリッドにおける独立館の数の增大が顕著である ${ }^{381}$ 。また、大き な変更を伴った地域は、クー・ラ・レンヌである。ここでは、中央 車道の位置を変更することによって、セーヌ川に沿って計画されて いる独立館をまとめて、セーヌ川側に建設することが可能になった。 このような操作によって、各独立館の平面の短辺の長さを中心とし て、平面外形または敷地外形が大きく変更されている。さらに、独

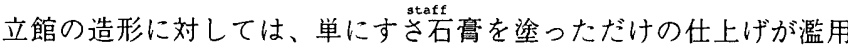
されることを整戒し、装飾を際立たせるための簡素な外観を求めた。 そして、この簡素な独立館を、彫刻、陶芸、モ゙ザイク等、さまざま な装飾美術の作品によって独立館に装うという、その設計手法に対 する基本方針についても、会場計画と関連づけて示されている。

これに対して、ギャラリーには、前案の大小関係をより発展させ て、グラン・ギャラリー内にも主従関係が設けられた。これにより、 ギャラリーそれぞれの関係をより明確にしている（図－3、4）。具体 的には、両端に塔を持つグラン・ギャラリーを主、キャーンコンス のギャラリーを従という位置付けを行った 39 ) そして、前案で平面 が連続していたグラン・ギャラリーは、この位置付けによって、そ れぞれのギャラリーの突出した部分を切り離した。この変更により、 ギャラリーは、軸性をより強調し、エスプラナード・デ・ザンヴァ リッドにより明確な秩序を与える骨格へと発展している。

一方、このような独立館とギャラリーのスケール操作によって、エス プラナード・デ・ザンヴァリッドのセーヌ川対岸から望むアンヴァリッ 
ドに、塔を用いた都市スケールの造形を試みた（図-4、5）40)。アレク サンドル 3 世橋の各端部に設けられた最も低い 4 棟の装飾塔に始まり、 ブティックの端部に設けられた 4 棟の塔、そして、グラン・ギャラリー の端部に設けられた最も高い4棟の塔が、それぞれ軸線対称な位置にそ びえ立つ41)。これらの塔は、グラン・パレ及びプティ・パレ側から徐々 に高さの增すように計画され、鳥㒈を誇張した彫刻的な造形手法によっ て、アンヴァリッドの眺望を魅了しようとしていたのである。

第 2 点目は、展示のより優れた方法を求めている点である。この 方法を具体化する上で重要な点は、1922 年3月案の作成に先立って まとめられた基本方針の中で、「フランスと諸外国との対置関倸」と 「展示物の『分類」」に対するそれぞれの対応を、会場計画案の中で 具体的に表現することであった。そのため、ルイ・ボニエは、この $2 つ の$ 対応をより明確に見える形で会場の中に描き出している。ま ず、会場を描き出すにあたって、展示空間を構成するグラン・パレ、 ギャラリー、独立館の3 種の建築に基づいてまとめている。

ギャラリーは、その配置が軸性対称であるため展示空間が同じ広 さとなるように、ファベール通り側のギャラリーをフランス部門に、 コンスタンティンヌ通り側のギャラリーを外国部門にそれぞれ割り 当てた (図 -4） ${ }^{42)}$ 。グラン・パレも同様に、南側がフランス部門に、 北側が外国部門に均等に割り当てられた。さらに、七ーヌ川を隔て て、エスプラナード・デ・ザンヴァリッドにはフランスの独立館を、 対岸のクー・ラ・レンヌには諸外国の独立館を建設することが計画 された。このように、ルイ・ボニエは、アンヴァリッド、セーヌ川 及びグラン・パレの強い軸性を活かして、「フランスと諸外国との対 置関係」を、会場の中に描き出そうと試みていたのである。

さらに、この関係をより明確に表現するために「展示物の「分類」」 を用いて、展示の位置関係を厳密に決定した。特に、「群」を中心に行 われている。具体的に、ギャラリーには、七ーヌ川側から第 1 群の 「建築」と第 2 群の「萣具」が、グラン・パレ 1 階には第 2 群の「家具」 と第 3 群の「衣装・装身具」が、グラン・パレ 2 階には第 4 群の 「㖃場・佳路・庭園芸術」と第 5 群の「教育」が割り当てられた

このように、本案は、前案同様、計画の精度をさらに向上させただ けではなく、敷地に関連する条件及び問題点と、開催意義に関連し た条件に対するすべての対応が、会場計画案の中に具体的に描かれ ていることがわかる。こうした点において、本案は、独立館のより 詳細な設計を除き、会場に対する明確な方針と高い精度を備えてい る点において、招待国に通知できるまでの完成度を持ったものに改善 されていると言えよう。

\section{1924 年 1 月案一敷地を拡張した会場計画案}

一方、1924年開催に向けた本博覧会の計画は遅れ、パリ市議会に おいても延期が議論された ${ }^{44)}$ 。そして、1923年3月17日に、植民 地博筧会の開催が予定されていた1925年に、本博覧会を開催するこ とが合議された。これに伴って、植民地博覧会による本博覧会への 敷地の委譲に関する協定も、1925 年への延期を認めることとなる。

本博覧会の建設工事は、1.924 年 3 月 26 日に工事部長を勤める建 築家シャルル・プリュメの指示により開始された45)。したがって、本 案は、ほほ土事開始前の実施案に最も近いものであると考えられる。 本案と前案の最大の相違点は、敷地が拡張されたという点である

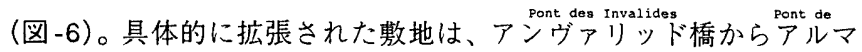
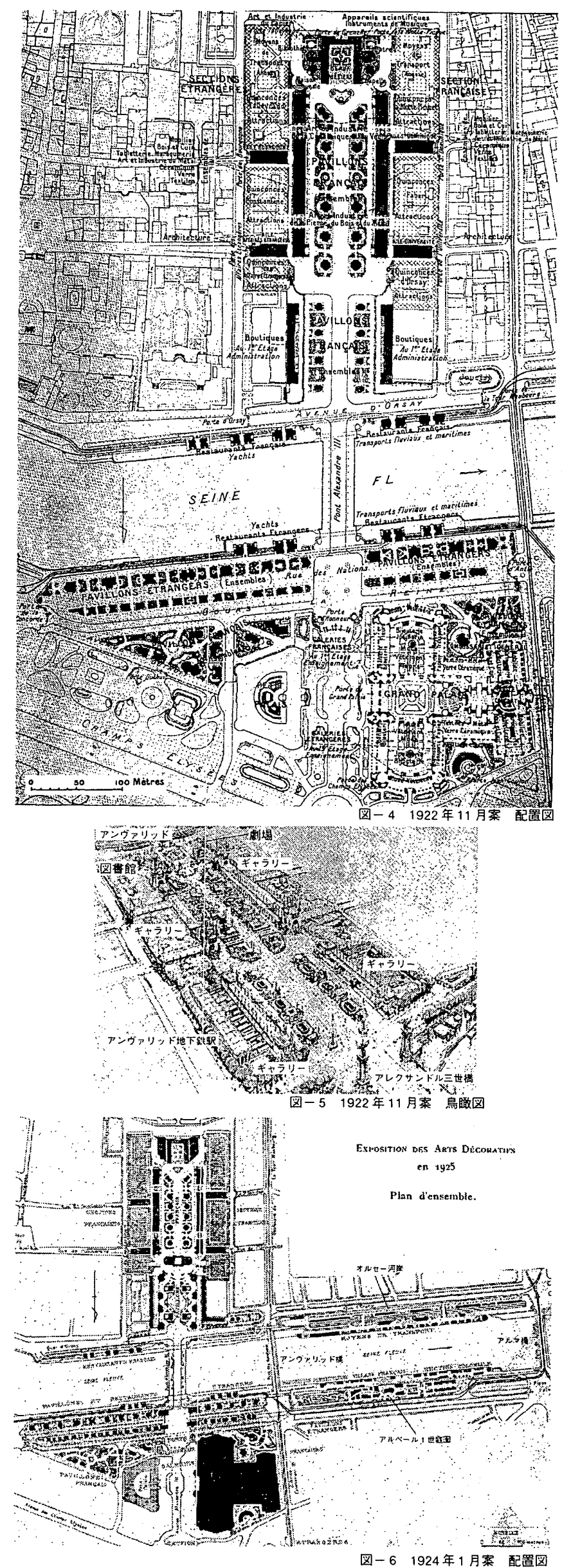


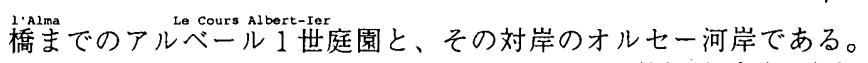
アルベール1世庭園は、パリ市が1925年7月まで、国立園芸協会と 賃貸契約を交わた地域であるため、前案までは、本博覧会の敷地で はなかった地域である。本案では、アルベール1世庭園には、溒芸、

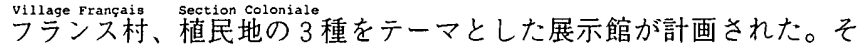
の対岸のオルセー河岸には、前案においては、キャーンコンスに計 画されていた輸送手段をテーマとした展示館等が配置されている。 この拡張された敷地とクー・ラ・レンヌ及びオルセー河岸は、アン ヴァリッド橋によって切り離され、さらに路面電車の軌道部分と交 差する地域である。そのために、この2つの敷地は、当初の計画で 取り上げられた歩道橋によって連絡することが計画された。

このように、拡張された部分以外のエスプラナード・デ・ザンヴァ リド等の会場においては、いくつかの細部に関する変更がなされて いるが、基本的な方針と会場の構成は、前案のものを踏襲している。

\subsection{5 年 5 月案一開催時の会場計画案}

本博覧会は、1925年 4 月 28 日に開会された。この案は、会場全 体の構成に関して、前案との相違点が1点しかない46)。それは、当 初計画していたものとは大きく異なる平面外形を持つ展示館が、多 く計画されているという点である(図-6、7） 47)。具体的には、特に、 セーヌ河岸のクー・ラ・レンヌに計画された外国館と、アルペール 1 世庭園に計画された園芸、フランス村、植民地に関する展示館に多 く見られる。諸外国の独立館は、1924年 1 月案において計画された 独立館よりも規模の大きいものが林立し、展示館の間に余空間とな る庭園がほとんど確保できないほどに密度高く計画されている。

一方、シャルル・プリュメは、ルイ・ボニエの同意を得て、この 会場計画において展示館の配置計画をまとめている。ここで、シャ ルル・プリュメが、本案の中で最も重視しているエスプラナード . デ・ザンヴァリッドに対する考え方を整理すると、次の 3 点にまと めることができる ${ }^{48)}$ 。第1点目は、この会場全体を統一感のある構 成にすることである。第 2 点目は、セーヌ川からアンヴァリッドに 至るガリエ二通りの単調さを緩和することである。第 3 点目は、ア ンヴァリッド・ドームに至る眺望を尊重することである。

このように、ルイ・ボニエとシャルル・プリュメのエスプラナード. デ・ザンヴァリッドに対する考え方は、1点を除きほぼすべての点が 共通している。その相違点は、セーヌ川からアンヴァリッドに至るガ リエニ通りを中心としたエスプラナード・デ・ザンヴァリッドの構成 に対するものである。それによって、エスプラナード・デ・ザンヴァ リッドの構成が、初期の案から次第に単調さが緩和され、独立館の配 置が複雑な構成へと変更されたことは、ルイ・ボニエとは異なった シャルル・プリュメの考え方によるものであると考えられる ${ }^{49) 。 ~}$

\section{8. エスプラナード・デ・ザンヴァリッドー独立館の検討過程}

このように一連の会場計画に関する考察から、エスプラナード。 デ・ザンヴァリッドは、ギャラリーを会場の骨格と捉え、丹念に検 討が繰り返されてきたことがわかる。その理由は、エスプラナード. デ・ザンヴァリッドのギャラリーが、1922 年3月案から修正を重权 るごとに、様々な条件を巧みに利用しながら、アンヴァリッドの軸 性に対する強い意識を、より明確に表すものへと改善されてきたか らである。加えて、ルイ・ボニエとシャルル・プリュメの会場の捉

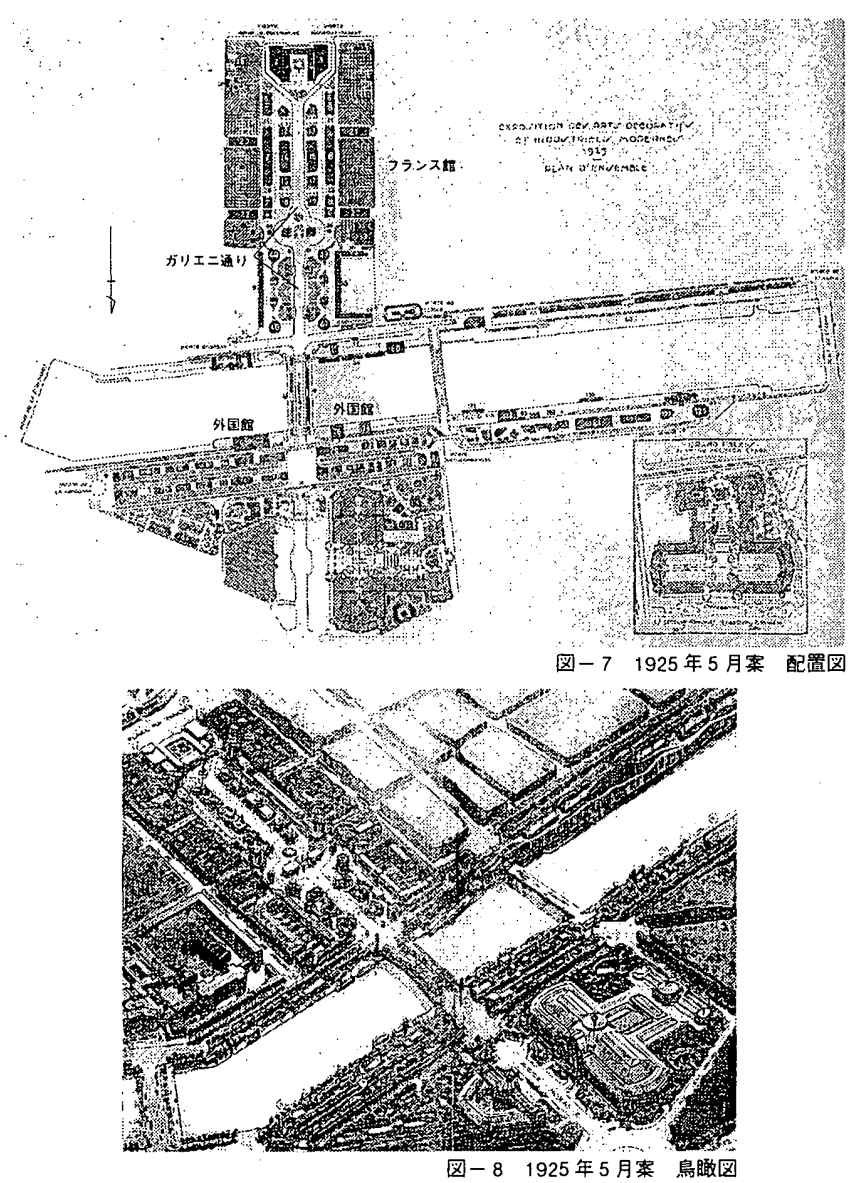

え方にも、エスプラナード・デ・ザンヴァリッドを中心会場とする 意図が現れている50)。そこで、エスプラナード・デ・ザンヴァリッ ドの計画過程をより明確に捉えるために、独立館を中心としてそれ ぞれの案の相違点を整理すると、以下 3 点にまとめることができる。

第 1 点目は、エスプラナード・デ・ザンヴァリッドのグラン・ギャ ラリーに挟まれた位置に計画されている独立館の平面寸法の変更点に ついてである(図-2、3、4、6)。1922 年 3 月案では、12 棟の独立館 の平面は、長辺及び短辺がそれぞれ約 $25 \mathrm{~m} 、 15 \mathrm{~m}$ の東西方向に長い

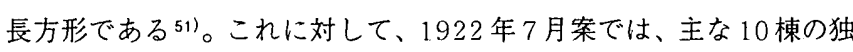
立館の平面は、長辺及び短辺がそれぞれ約 $15 \mathrm{~m} 、 11 \mathrm{~m}$ の南北方向に 長い長方形に、その他の 2 棟の平面は、面積が $88 \mathrm{~m}^{2}$ の長方形に変更 されている52)。しかし、1922 年11月案では、主な 8 棟の独立館の平 面は、一辺が $15 \mathrm{~m}$ の正方形に変更され、1924 年1月案においても、 この大きさが踏襲された。最終的に、主な10棟の独立館の平面は、一 辺が $16 \mathrm{~m}$ の正方形を基本とした幾何学形に決定された ${ }^{53 !}$ このよう に、独立館の平面は、当初から一貫して幅が $16 \mathrm{~m} て ゙$ 計画されてきた ギャラリーとその幅を統一することによってエスプラナード・デ・ザ ンヴァリッドの会場構成に一秩序を与えるように変更されている ${ }^{54)}$ 。 第 2 点目は、エスプラナード・デ・ザンヴァリッドのグラン・ギャ ラリーに挟まれた位置に計画されている独立館の平面形状の变更点 に関してである。1.922 年 3 月案、1922 年 7 月案において、独立館 の平面は長方形であったが、1922 年 11 月案以降の案では、独立館 の平面は、正方形を基本とした十字形、その四隅を隅切りした八角 形等によって与えられるようになる(図-2、3、4)。

第 3 点目は、プティ・ギャラリーに挟まれた敷地の独立館に関し てである。1.922 年 11 月案からこの地域にも独立館を建設すること 
が計画され始めた（図 -4）55)。この地域に与えられた独立館の平面 は、長辺及び短辺がそれぞれ約 $12 \mathrm{~m} 、 10 \mathrm{~m}$ 東西方向に長い長方 形を基本として与えられた。しかし、1924年 1 月案においてギャラ リーとともに大きく変更される(図-6)。具体的には、ギャラリーの 端部に設けられていた塔を撤去し、ギャラリーの偪を細くするとい う操作に伴い、その内側に計画されている独立館は、12 棟に増加さ れ、四隅に平面の大きい独立館を、その内側に平面の小さい独立館 を幾何学的に配置している。この四隅に配置された独立館の平面は、 一辺が $20 \mathrm{~m}$ の正方形を基本とした正八角形で、この会場に計画され ている独立館の中でも最も規模が大きいものの1つである。さらに、 塔を除いた他の展示館よりも高さのある独立館の計画が求められた。 このような点から、この 4 つの独立館に、1922 年11月案において プティ・ギャラリーの両端に計画されていた 4 棟の塔による会場の 造形的な役割を与えるという操作がなされたことが確認できる。

\section{9. 結}

このように、現代装飾美術・工芸美術国際博覧会の会場の計画過 程を明らかにした。この考察から明らかになったことを整理すると、 以下の 3 点にまとめることができる。

第1点目は、会場計画に最も大きな影響を与えた敷地の連続性に関 してである。ルイ・ボニエは、これに対して、アンヴァリッドからグ ラン・パレ及びプティ・パレに対する軸性と、それに直交するセーヌ 川に沿った方向性を、会場全体をまとめる最も基本的な敷地条件と認 識している。具体的には、単にアンヴァリッドを会場の背景として尊 重するという視点のみから軸性を重視しているわけではない。ルイ。 ボニエは、エスプラナード・デ・ザンヴァリッドのギャラリー、独立 館及び、庭園による会場計画では、この軸性をより強調する方針で修 正を続けた。また、アレクサンドル 3 世橋の装飾灯と各ギャラリーの 塔による会場計画についても同様に、この軸性を強調し、垂直方向に 広がりのある視覚的な演出を行っている。さらに、クー・ラ・レンヌ 及びオルセー河岸では、路面電車の地下埋設化によって敷地の連続性 を高めただけではない。ルイ・ボニエは、セーヌ川に沿った方向性を 重視して、独立館及び庭園の平面及び配置を決定することによって、 水平方向への広がりのある会場を計画した。このように、軸性と方向 性は、会場の全体及び各地域にそれぞれのまとまりを与えている。

第 2 点目は、ギャラリー、独立館、庭園等による会場構成につい てである。この会場は、ルイ・ボ二エの基本方針に沿って計画され たものであるが、その基本方針は、敷地に関連する条件及び問題点 と、開催意義に関連する条件を巧みに利用することによって、会場 全体に配分と均整という2つの秩序を与えるために有効なものとし て受け入れている。一方、本博覧会は、その開催意義において、展 示館を含めたすべての分野の展示に対して、新時代の新しい造形を 求めていたため、近代の新しい造形に対する期待と、新奇性のみを

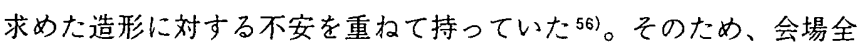
体に与えられた秩序は、このような未知の独立館の配置、規模及び、 形態を制御するとともに、異なる新しい展示館、会場及び周辺都市 との調和をもたらすことが期待されている。実現した会場では、エ スプラナード・デ・ザンヴァリッドのフランスの独立館は、計画通 りの秩序と調和のある会場構成に基づいて、ゆとりのある庭園に囲 まれたものであった。一方、クー・ラ・レンヌの諸外国の独立館では、
当初の計画とは異なる平面の独立館が、十分な余空間を取らずに計 画された。この背景には、ルイ・ボニエが、フランスの独立館の配 置、規模、形態を制御する意図が明確であるのに対して、諸外国の 展示館に対しては、新造形を求める開催意義との矛盾から、明確な 制御を示さなかったからであると考えられる。

第 3 点目は、ルイ・ボニエとシャルル・プリュメの会場計画への 取り組みに関してである。この会場計画において、両者が計画した 部分を正確に分けて明確化することは、非常に困難である。しかし、 敷地の選定から一貫して本博覧会に取り組んできたルイ・ボニエの 敷地に関する理解は、会場の基本方針を打ち出すために有効なもの であった。一方、会場の骨格が形成された 1922 年 11 月案以降、工 スプラナード・デ・ザンヴアリッドの会場に対する見解の相違から、 明確に会場の構成が単調なものから複雑化される背累には、シャル ル・プリュメの影響があったと考えるのが自然であろう。

以上のように、ルイ・ボ二エは、本博覧会の会場を一つの大きな 方針に沿って、エスプラナード・デ・ザンヴァリッドを中心に計画 したことを明らかにした。これを受けて、主要展示館に関する考察 は、稿を改めて述べたい。

註

1）三田村哲哉、小林克弘、「1925年パリ現代装飾美術・工芸美術国際博覽会の影地 選定に関卞歹考察」日本建築学会計西系論文集、563号、2003年1月、pp.321-326 2）吉田鋼市、「アール・デニ博とオーギュスト・ペレ小、建勧史学、第 2 号、 1984 年 4 月。及び、三四村哲哉、小林克弘、中原まり、「パリにおける博覧会 の変要に関する研究ー185う-1937年を対象とした配酉計画の分析を中心とし てー小、日本建策学会計画系論文集、519 号、1999年う月、pp.333-339。

3）6つの会場計画案は、それぞれ発表导れた年月をその案の名称として表した。具 体的にそれぞれの案を列挙卞ると、「1.922年3月案小「1922年7月案」、「1922

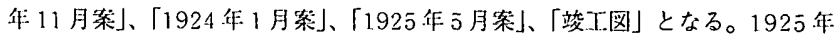
万月案は、既往研究に多く㵧载きれているが、それ以外の会場計画案は、筆者 が当時の建筑誌等から選出したものである。また、1925年万月桇は、咬工図と 細部において買なる部分があり、建設開始後においても、計画の変更が繰り返き れていたと考えられる。兰らに、唆工図は、閉会後に発表きれた図面であるとい

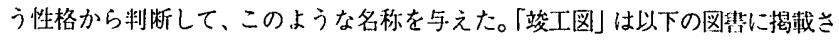
れている。cf. Fernand David,Paul Léon, Louis Nicolle, Henri Marcel Magne, Ministère du Comnerce de L'Industrie des Poste et des Télégraphes, Expositition Internationale des Arts Décoratifs et Industriels Modernes Paris 1925:Rapport Général:section Administrative 4 Plans Construction \& Amenagement des Bâtiments et des Jardins, Larousse, Paris, 1931, Bibliothéque du Conservatoire National des Arts et Métiers

4）この展示館の面皘等に関する報告黙は、各地域一の展示館の分配、展示会場の 面積算定、馓示館の平面形状、建设予算等の検討をまとめた面積表である。

5) 実施図面の配置図は、アンドアリッドの正門の中心を基準として、エスプラナー

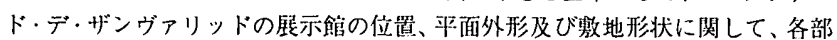
分に寸法を表したものである。○f.Exposition Internationale des Arts Decoratifs et Industriels Modernes, Esplanade des Invalides et Couverture de la Gare, Plan Général, MINUTE 8861, DUPLICATA 9351 Archive de Paris,VR252，縮尺 1/200、大きき: 維約 $282.5 \mathrm{~cm}$ X横約 $138 . \overline{5} \mathrm{~cm}$

6）测量図は、笑施图面同㥞に、アンヴァリッドの門の中心を基準して、エスプラ ナード・デ・ザンヴァリッ・の細部にわたる形状、位置、高低差が、20 mグリッ ドを基準として描かれている。○f. Direction des Services d'Architecture， 26 mars 1924, Archive de Paris 所藏，VR251，縮犬' 1/200

7)教地に関連する条件と問題点は、「植民地博臨会より委撞された際に課せられた 条件小、教地の地理的及び閭辺環境に伴う条件小「開催期間中の一般交通に関す る問題」にまとめられる。三昆村哲哉、小林克弘、Op.cit.，1)，pp.321-326

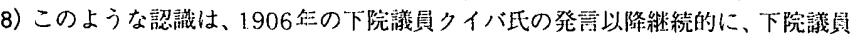
ロブラン氏などのきまざまな人物によって言及きれ、より明確にかっ具体的なも のへと発展していくっcf.Dccuments parlementaires:annexes aux procèsverbaux des séances:projets et propositions de loi, exposés des motifs 
et rapports/Chambre des deputes, Imprimerie du Journal officiel, Paris, 13 juillet 1906,pp.1545-1673, et 1 juillet 1912,pp.1436-1455

9）さらに、このような認識は「模做禁止」という言葉に代表されるように、過去 の様式や複製品を否定するような考え方に至るものである。cf.Roger Marx， "De l'Art Social et de la Nécessité d'en Assurer le Progès par une Exposition", Idées Modernes, tome Premier, H.Dunod et E.Pinat Editeurs, Paris, janvier 1909,pp.46-57

10）この「展示物の「分類』」、1855年のパリ万国博覧会から伝統的に用いられ てきた展示に関する基本指祭である。cf．龍鳥茂、「絶䜿、パリ万国博臨会」、 河出㫪房新社、東京、1992、pp.98-1.61

11こうした背景には、1900年パリ万国博覧会闒会後、装飾美術に関する関心の 高まりによって、1911 年にロベール・ギレーレ (Robert Guilleré) が建 築及び装飾美術の技術向上を主張したことが大きく影犁している。

12）吉田鋼宁、Op.cit. ,2),pp.61-62

13）本文中において、「展示領」は「独立館（Pavillon isolé）」「ギャラリー (Galeries)」、「グラン・パレ (Grand Palais)」を表す。

14) Signé:Fernand David, Angoulvant,"Convention relative aux emplacements à concéder éventuellement par l'Exposition coloniale à l'Exposition des arts décoratifs modernes-Convention additionnelle no.1",Paris, le 7 novembre 1921, Article Premier

15) Louis Bonnier, "Rapport à Monsieur le Commissaire Général", 16 décembre 1921,p.15, Institut Français d'Architecture-Centre d'archives d'architecture du XXe siècle, Fonds Louis Bonnier, "Exposition des Art Décoratifs de Paris 1925 Dossier de Préparation et Suivi",35/70 (以下、上嫏のコレクションをArchive d'IFA Fonds L.B. と記市。)

16) Louis Bonnier,"Exposition Internationale des Arts Décoratifs Modernes",février 1922, Archive d'IFA Fonds L.B.

17) Louis Bonnier, Op.cit.,16)

18）独立館、グラン・パレ、ギャラリーの中で違いが特に明砇ではないのは、グ ラン・パレとギャラリーであった。そのため、ギャラリーは特別な構想を持っ た、執務室、涭室、食堂などの具体的な室に展示きれることが求められた。 Louis Bonnier, Op.cit., 15), pp.6-7

19) Louis Bonnier, Op.cit.,16)

20) Louis Bonnier, op.cit., 15), p.2

21）フランスの独立領では、独立館自体も展示品であるという捉えうによって、地

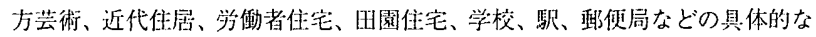

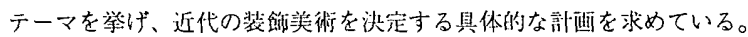

22）幅 $16 \mathrm{~m}$ という大ききは、ギャラリーを中版下型を基本とした模成とする意図 から生じたものである。具体的には、中块通路を $4 \mathrm{~m}$ 、间侧の展示会場を $6 \mathrm{~m}$ という幅の検討によるものである。この幅は、配置図の寒施図面から、有效で 幅 $16 \mathrm{~m}$ であることが倠認できる。Louis Bonnier,Op.cit.,15),p.4

23) F.Honoré, "L'Exposition Internationale des Arts Décoratifs", L'Illustration, 4 mars 1922 , no. 4122 , p. 212

24）キャーンコンスには、重姴度が低く認識された屡示館が計西きれ、緑地带の中 に建設されることから、庭囷と組み合わせて計画するという意図はない。

25）この問題は、「開催期間中の一-般交通に関する問題」の中でも重琶な問題であ り、歩道橋を設けるという案は、このほかの交通問題とともにパリ市誐会にお いても議諭きれている。cf."17-Modification des emplacements de l'Exposition des arts décoratifs et industriels modernes", Bulletin municipal officiel de la ville de Paris, Imprimerie municipale, Paris, mardi 10 juillet 1923,pp.3008-3010

26）ルイ・姑二工は、会場部画案の作成に対す万面皘表及び、閔会後までの工程表 を報告書にまとめている。cf.Louis Bonnier,"Exposition Internationale des Arts Décoratifs \& Industriels Modernes en 1924", Direction des Services d'Architecture et des Travaux No.8,9 juillet 1922, Archive d'IFA Fonds L.B.

27）各展示館に与えられた面積が、政地面積であるのか建筑面皘であるのかの判断 は非常に難しい。しかし、最終的に建筑外形と捉えて設計光れた展示館が多い ことから与えられた面積は建築面積と捉え、図䤄においては建築坐形であると 判断した。而積表には、"Surfaces Constructibles"と記されている。

28) Louis Bonnier, op.cit., 26), pp. 6-7

29）地下がアンヴアリッド地下鉄駅の敷地に計画芑れているものをプティ・ギャラ リー(短辺 $1.0 \mathrm{~m}$ )、その他のものをグラン・ギャラリー(短辺 $16 \mathrm{~m})$ とした。

30) Louis Bonnier, op.cit., 26),pp.9-10

31) G.J." "L'Exposition des Arts Techniques de 1924 II-Le programme Architectural de M. Louis Bonnier", Le Bulletin de la vie Artistique, ler juin 1922,p251

32）図彗館と侌議場は計画段階のもので、実現したのは図書館と劇場である。また、 図書館と劇場の間の技能館は、計画段階では、ギャラリーとして扱われていた。

33)歩道橋を架ける条がパリ市議会等でも反対された理由は、眺望を損なうことと、 歩道橋のみによる交通に難しきが残るからである。また、路面電車の地下埋設 化は、1900年パリ万国博覧会の時と同じ方法であり参考にきれている。cf.25)

34）日本に送付されたもの：「各国博覧会関係雑件，別冊万国装飾美術丁芸博覧会 第一巻 自大正十二年六月、至大正一三年十二月」、外務省外交資料館

35) Louis Bonnier, rapport, 1922?, Archive d'IFA Fonds L.B.

36）会場内の樹木の伐採仕禁止されていた。G.J.,Op.cit.，31)，pp.250-251

37) Louis Bonnier, Op.cit., 35), p.2

38）本案に烕しても前案と同様に、面穔計画が面積表によって表きれている。cf. Louis Bonnier," Exposition Internationale des Arts Décoratifs et Industriels Modernes", Archive d'IFA, Fonds L.B.

39) Louis Bonnier, Op.cit., 35), p. 2

40）ルイ・ボ二エの高きへの配感が述べられている。cf.G.J.,31),pp.252

41）前案において、アンヴァリッド地下鉄駅の上に建つ「プティ・ギャラリー」は、 「ブティック」に変更されている。

42) "Exposition Internationale des Arts Décoratifs et Industriels Modernes",M DCCCC XXII,Imprimerie Nationale, Paris, 1923, pp.3-7, Archive d'IFA Fonds L.B.

43) Op.cit. , 42), pp.13-24

44) Op.cit., 25), "Modification de la date d'ouvreture de l'Exposition des arts décoratifs et indutriels modernes", samedi 17 mars 1923,p.1346

45) "Inauguration des Travaux de l'Exposition des Arts Décoratifs" La Construction Moderne,Paris, 6 avril 1924,p.321

46）本案の配置図は、以下の図㫮にも揭載きれている。Michel Roux-Spitz， Batiments et Jardins-Exposition des Arts Décoratifs Paris 1925,Edition Arbert Lévy, Paris, 1925 (ミッシェル・ルッー・スピッ ツ糄、鈴木博之融、「アール・デコの建築と庭園」、学習研究社、1985)

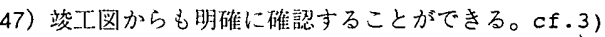

48) Michel Roux-Spitz,Op.cit.46),p.15 (ミッシェル・ルゥー・スピッッ 縟、鈴水博炎訳、Op.cit.46),p.15)

49シシャルル・プリュメは、こうした単調きを緩和するために、4本の塔に期待 したが、それはアメリカ旅行における磨天楼の経験によるものである。

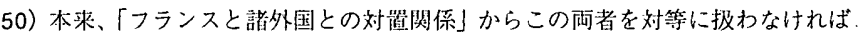
ならないが、最も広大な敷地であり統一感のある会場を構成できたという点に おいてエスプラナード・デ・ザンヴァリッドを中心会場として提える見方も あった。Michel Roux-Spitz,Op.cit.46),pp.15-16(ミッシェル。 ルッー・スピッツ編、鉿木博之款、Op.cit.46),pp.15-16)

51)長方形の辺の長さは、面皘表の而皘と比べながら配置図から実测したものである。

52) Louis Bonnier, Op.cit.35),p.3

53）アンヴァリッド地下鉄駅側の 2 棟の塔に隣接する独立館のみ幅が舅なる。

54）単密には、独立館は平面外形の一辺が $16 \mathrm{~m}$ の王方形で与えられているのに刘 して、ギャラリーは建物の有効寸法の内㧹で $16 \mathrm{~m}$ を取っている。cf.5)

55）この敷地は、アンヴァリッド地下鉄駅の上部であり、建築の建設及び庭園や 葸樹に関しても制約のある地域である。したがって、当初から、この部分に独 立備を皘極的に計画するとは考えにくい。

56) Op.cit. 42 ), pp. $3-4,25$

図版出典（全図版に施設名等を篚者加篚。図一3は天地逆に掲藏した。）

图-1 L'Illustration, 4 mars 1922,no.4122,p.212

図-2L'Illustration, 4 mars 1922 , no. 4122 ,p. 213

图-3Discours de M. Le Sénateur Fernand David,Réunion de 7 juillet 1922, Société d'Encouragement à l'Art et à l'Industrie, Imprimerie Henri Diéval, Paris

图-4 Exposition Internationale des Arts Décoratifs et Industriels Modernes, M DCCCC XXII, Imprimerie Nationale, Paris, 1923

图-5L'Illustration, 18 novembre 1922, no. 4159, p. 484

図-6 "Exposition des Arts Décoratifs en 1925 plan d'ensemble", La Construction Moderne,Paris, 13 janvier 1924,no.15,p. 174

图-7 "Exposition Internationale des Arts Décoratifs et Industriels Modernes 1925 Plan d'ensemble", La Construction Moderne, 3 mai 1925, no. $31 \mathrm{pl} .122$

图-8 Paul Géraldy,"L'Exposition Internationale des Arts Décoratifs et Industriels Modernes - L'Architecture Vivante", L'Illustration, 25 avril 1925, no. 4286 